\author{
АЛЕКСАНДАР М. МИЛАНОВИК* \\ Универзитет у Београду \\ Филолошки факултет
}

\title{
О ЛЕКСИЧКИМ КАРАКТЕРИСТИКАМА ЋОСИЋЕВЕ ДНЕВНИЧКО-МЕМОАРСКЕ ПРОЗЕ
}

\begin{abstract}
У раду се анализира стилски маркирана лексика у Ћосићевојдневничко-ме-

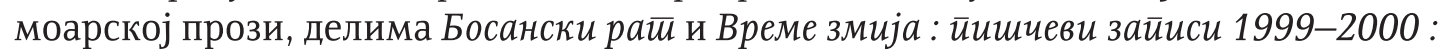

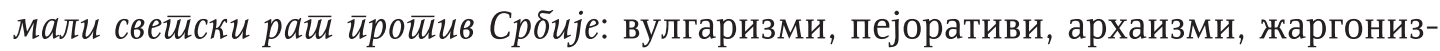
ми, колоквијализми и, нарочито, индивидуални неологизми. Стилски маркирана лексика, која је карактерисала и претходна Ћосићева дела сродне природе, приближава ова дела публицистици, нарочито журналистици у колумнама.
\end{abstract}

Кључне речи: вулгаризам, пејоратив, архаизам, кроатизам, жаргонизам, колоквијализам, индивидуални неологизам, оказионализам.

1. Иако је широј читалачкој публици мање позната од романа, иако јој је у књижевној критици посвећена мања пажња него романима, Ћосићева дневничко-мемоарска проза, различито жанровски одређивана и од стране самог аутора и од стране тумача, ${ }^{1}$ већ је била предмет истраживања у оквирима науке о књижевности и науке о језику. У домену лингвистике аутор овог прилога још је 2005. утврдио да се по значајним (ако не и функционално доминантним у дневничко-мемоарској прози) стилским поступцима Писии моїа века (2002) не разликују превише од Ћосићевих романа, нарочито у области синтаксе, издвајајући при томе парцелацију, елипсу, синтаксички паралелизам, понављање и удвајање субјекта (Милановић 2005). Разлике у избору лексике у романима и дневничким фрагментима, тј. одсуство дијалектизама и локализама, а присуство неологизама из политичког дискурса у Писиима моїa века, протумачене су разликама у тематици, садржају и функцији дела, док

*aleksandar.jus@gmail.com

${ }^{1}$ Ана Ћосић Вукић (2012: 275) износи како је Босански рай настао „из обимне и тематски разноврсне грађе дневничких записа, публицистичких текстова и личне архиве". Иста ауторка, раније и на другом месту, gневничке зайисе назива и „дневничке белешке” (Ћосић Вукић 2008: 245, 246, 256 итд.). И „записима” и „белешкама” фрагменте из gневника називао је и сам Добрица Ћосић (Ћосић Вукић 2008: 247). 
је у сличности синтаксичких поступака препозната Ћосићева жеља за поетизовањем тј. литераризацијом своје дневничко-мемоарске прозе.

У овоме раду направићемо покушај упоређивања стилски маркиране лексике и њених творбених својстава у Ћосићевим дневничко-мемоарским „записима” различитог садржаја, насталим различитим поводом и у различито време. Особинама које смо у претходном раду већ утврдили додаћемо анализе новијих Ћосићевих дела. У питању су

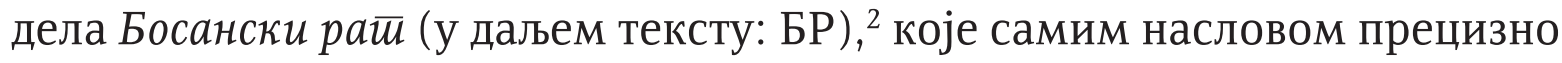
дочарава и догађај и време, и Време змија: йишиеви зайиси 1999-2000 :

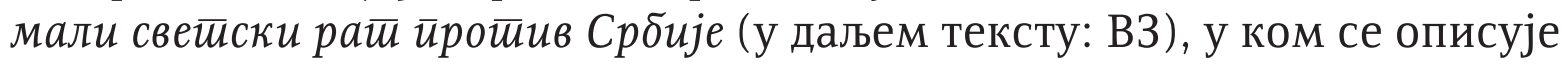
и коментарише бомбардовање Србије. Циљеви рада су да се установе поједине лексичке константе Ћосићеве дневничко-мемоарске прозе и направе паралеле са истим цртама у већ анализираном Ћосићевом делу.

2. У ВЗ и БР Ћосић је описивао и тумачио политичка и ратна збивања током 90-их година 20. в. из перспективе значајног и утицајног културног и политичког чиниоца на српској сцени. Иако му је књижевни ефекат овом приликом несумњиво био мање значајан од ефеката документарности и аутентичности, Ћосић је настојао да и ове своје записе тј. белешке стилизује поступцима који ће их приближити књижевном делу, истовремено их удаљавајући од пуке и монотоне фактографије коју је могао водити било који сведок, као и коментара који би спадали више у домен публицистике, а мање у област есејистике и књижевности. Тематика ових књига просечном интелектуалцу добро је позната будући да су описивани и тумачени догађаји из недавне прошлости, готово актуелни, а обиље података, описа догађаја и коментара Ћосић му је покушао учинити занимљивијим различитим језичко-стилским поступцима, више на синтаксичком плану, а мање у домену лексике. Иако су лексичке стилеме релативно ретке у овим текстовима, њихово порекло и функције заслужују више коментара и сведоче о посебним Ћосићевим поетичким замислима.

3. Као активни учесник, а не само сведок, бурних политичких и ратних збивања у Србији, Ћосић пише у повишеном емотивном регистру, тако да не преза ни од вулїаризама у осудама, и то пре свега војне силе коју сматра агресором. Иронична и пародијска слика вођа ове силе наглашена је вулгаризмима сисе и їузови: „презирући бандоглаве зликовце Србе који им одлажу ноћашња уживања међу женским бути-

${ }^{2}$ Књига је сачињена од фрагмената из Ћосићевих Пищчевих зайиса 1992-1993,

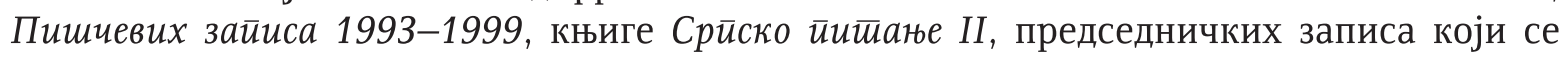
први пут објављују и фрагмената из увода за објављени дневник Николе Кољевића (Ћосић Вукић 2012: 276). 
нама, сисама и гузовима..." (B3, 15). Исту функцију у тексту, додајмо,

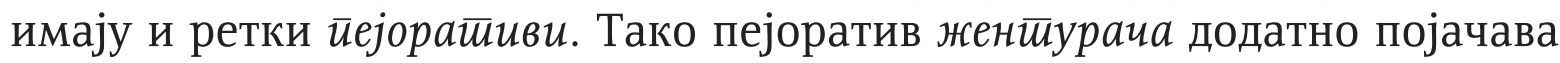
синтагму великог негативног набоја: „Чудим се зашто бедне грађанке и унесрећени грађани које оне званично теше - не најуре те фрустриране жентураче" (В3, 107).

4. Ироничан тон, пре свега, Ћосића води и другачијим изворима лексичког онеобичавања текста, па се у текстовима, сасвим ретко додуше, могу препознати и архаизми. Ћосић активирањем застареле лексике доказује да рачуна на образованог читаоца, спремног да препозна

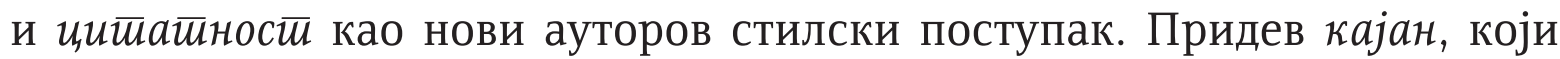
код свих призива пре свега стих чувене песме Лазе Костића Santa Maria della Salute (иако РСАНУ доноси и друге застареле потврде), то најбоље илуструје: „Та кајна самосвест није дуго трајала и није изазвала дужу патњу" (B3, 241).

Извор оваквих архаизама неретко је српска романтичарска књижевност, као у случају именице неразум, потврђене у РМС ('слаб разум; одсуство разума, безумље, безумност') примером из Змајеве поезије. У Ћосићевом тексту именица неразум има управо значење одсуства разума: „На таквом националном, религијском и политичком простору није требало много напора, али је било довољно мало историјског неразума да се покрене међунационални, грађански и верски рат" (БР, 135). Застарела је данас и придевска сложеница млаgолетиан, регистрована опет у РМС ('малолетан, малодобан'), уз један пример из Прерадовићеве поезије, а други из некњижевног текста. У оба наведена примера у речнику ова лексема ближе одређује особе, лица. И у РСАНУ, уз квалификаторе „правн. заст." ова лексема исто је дефинисана, уз обиље нових примера. Код Ћосића, међутим, ова лексема добија другачије значење, одређује именицу gaн, не особу, а у њој лешио нема значење 'година', већ 'годишње доба', па би је ваљало третирати заправо као пишчев неологизам: „Дан је младолетан, ветровит" (В3, 76).

Двоструко је маркирана и именица йлеменшйина. Она је истовремено и архаизам и, судећи према примерима из РМС и суфиксу, кроатизам, што Ћосић веома вешто стилски искоришћава у реченичном контексту: „Црна Гора се сурвава у племенштину, антисрпство, дукљанство” (B3, 240).

5. Сасвим је очекивано, с обзиром на друштвени статус и године аутора, што у Ћосићевој дневничко-мемоарској прози готово да и нема жарїонизама. Ипак, будући да се диви храбрости младих Београђана, међу којима је и његов унук Никола, Ћосић посеже за цитатима који илуструју њихов пркос и одважност. Такву функцију има и жаргонизам

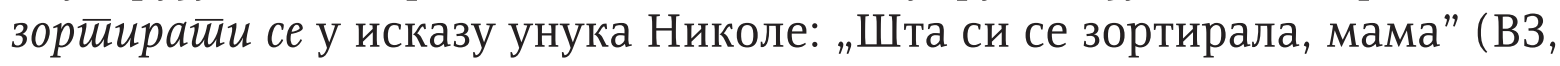


115). Занимљиво је да речници жаргона не бележе овај глагол, заиста жив у београдском жаргону, што сведочи да у поступку сказа Ћосић није вештачки стварао жаргонски бојене реченице, већ је пажљиво ослушкивао, и потом записивао, говор око себе. Наиме, Драгослав Андрић (1976: $62)$ бележи само именицу зорй, са значењем 'страх', а и Боривој Герзић (2012: 372), у речнику објављеном после Ћосићевих дела, региструје само именицу зориеер, са значењем 'кукавица'.

6. Бирајући позицију сведока који „из народа” посматра актуелне политичке догађаје, Ћосић активира и бројне савремене и помало преживеле колоквијалне изразе за особе укључене у политички живот у најширем смислу, готово по правилу са веома негативним конотацијама. Овим колоквијализмима писац као да стаје на страну „народа”, идентификујући се, преко говора, са његовим мишљењем. Примера је више: а) уgбоващ: „Мртви су сви чувени и славни удбовци” $\left(\right.$ В3, 97); ${ }^{3}$ б) јуловка: „То су жене политичара, јуловке” (B3, 107); ${ }^{4}$ в) комуюара: „Миру Марковић смењује Даница Драшковић: 'комуњару' смењује 'четникуша'" (B3, 113); г) иейникуша: „Миру Марковић смењује Даница Драшковић: 'комуња-

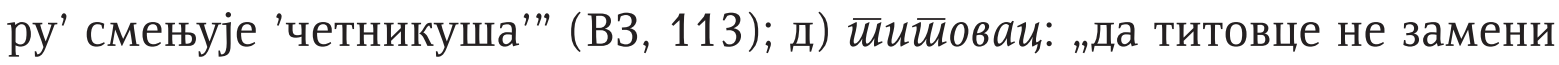
равногорцима” (В3, 177); „мисле мондијалисти и титовци” (В3, 196); ђ) равноїоращ: „да титовце не замени равногорцима" (В3, 177).

Усамљени пример са комуњаром и иетиникушом показује како се Ћосић само изузетно опредељује за решење у којем цитатност наглашава наводницима, и то само када има негативан суд о претераном народском жигосању. ${ }^{5}$ Сви наведени примери активираних колоквијализама Ћосићев израз јасно приближавају публицистичком, још ближе журналистичком, а нарочито оном карактеристичном за актуелне колумне, у којима новинари често посежу управо за колоквијалним изразом у коментарима актуелних збивања.

7. Језик Ћосићеве дневничко-мемоарске прозе лексички је најубедљивије маркиран пишчевим индивидуалним неологизмима. Они су творбено посве различити и подразумевају све доминантне начине творбе у српском језику, што сведочи о добром језичком осећању пишчевом и његовој језичкој креативности, недовољно запаженој у литератури.

7.1. Ћосић је у анализираним делима био склон ковању сложеница које су свесно у рубним областима творбене исправности. Блискост оказионализмима или прелазак у сферу језички недозвољеног писцу су по-

${ }^{3}$ Доминатан колоквијални израз за припадника некадашње Удбе био је и остао ygбаш. Тешко је рећи зашто је Ћосић одабрао мање фреквентну лексему.

${ }^{4}$ Мисли се на супруге чланова странке ЈУл (Југословенска левица).

${ }^{5}$ У речнику Б. Герзића (2012: 155) уз комуюара стоји: „pogrd., polit. pristalica komunizma, komunista". 
жељни, он жели да читаоца изненади чудноватом лексичком креацијом, тера га да се замисли над њеним склопом и значењем и да препозна иронију, па сарказам, који су чести при опису и коментарима политичких и ратних догађаја. Иронији и сарказму подвргнути су подједнако и агресори и режим Слободана Милошевића, али и млад свет новокомпонованих богаташа, који, имун на патње „народа”, беспослен седи по кафићима: а) gржавоборачки: „Тај пожаревачки деспот, с комунистичким својствима а државоборачким циљевима, необично је лукав и бескрупулозан у својим амбицијама” (БР, 89); б) свакочасовно: „Телевизовано човечанство нас презире, јер се свакодневно, свакочасовно убеђује да смо извршили етничко чишћење и колективни злочин над Шиптарима" (В3, 58); в) мостиобрански: „У српској мостобранској храбрости има много лакомислености” (В3, 60); г) млаgоуживалачки: „Пролазећи ноћас поред кафића 'Паспорт' на крају улице Васе Пелагића, опет сам се застидео због младоуживалачког 'џет-сета'" (В3, 212).

Ћосић је на више места у обе књиге активирао и помало архаичну

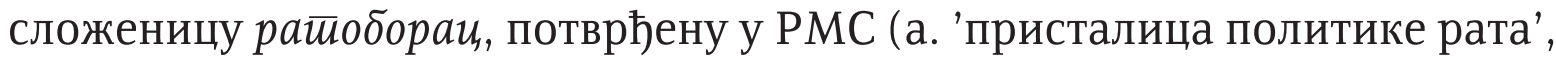
б. 'ратник'), и то у првом наведеном значењу: „Ми ћемо бити не само народ сотона, народ варвара и зликоваца, како нас називају, него и народ безумних ратобораца” (БР, 143); „Од ратоборца је постао миротворац, чему се радујем и у чему смо истомишљеници” (БР , 145); „Подизање оптужнице је морална и политичка инјекција поколебаним ратоборцима" (B3, 132). Према њој, међутим, стоји у обе књиге и непотврђена имени-

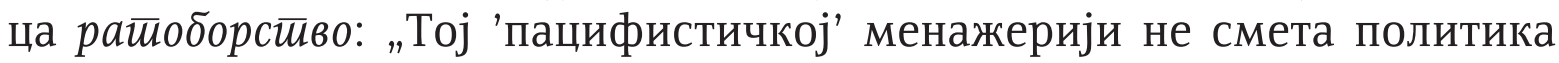
Ватикана и исламске заједнице и њихово ратоборство” (БР, 185); „Хитлер и Мусолини, нацистичке и фашистичке вође, у свом ратоборству изражавали су бес, жестину, огорчење према онима које желе да победе и униште" (B3, 68). Ћосић, дакле, није одабрао постојећу именицу ра$\bar{u} о б о р н о с \overline{u ~(Р М С: ~ ' о с о б и н а ~ о н о г а ~ к о ј и ~ ј е ~ р а т о б о р а н, ~ р а т н и ч к о ~ р а с п о л о-~}$ жење'), већ суфиксом -сшиво изградио неологизам.

7.2. Сасвим је нов и глагол ойpupogūu $u$, у значењу 'учинити природним', добијен комбинованом, истовременом сложено-суфиксалном творбом $\left(o^{-}+\bar{u}\right.$ pupog- $\left.+-u+-\bar{u} u\right):$ „Техницизирану средину покушава да оприроди блудом" (B3, 239). Комбинованом творбом добијен је и Ћосићев неологизам вишеличје (више- + лик- + -je): „Ако би у том вишеличју требало именовати вертикале, то су слобода и трпљење" (B3, 201).

7.3. У своме лексикотворству Ћосић радо бира и извођење, најтипичнији начин творбе нових речи у српском језику. Иако по својој природи мање експресивне, Ћосићеве нове изведенице неретко изненаде креативношћу и стилским ефектом који производе. Чини се да му постизање одговарајућег ефекта највише полази за руком при творби нових 
придева. Таквим, на пример, сматрамо придев иелевизован: „Телевизовано човечанство нас презире, јер се свакодневно, свакочасовно убеђује да смо извршили етничко чишћење и колективни злочин над Шиптарима" (B3, 58). Наглашавање негативне пропагандне, агитационе улоге српске естраде током бомбардовања постигнуто је стварањем придева есйраgерски, будући да је придев есиираgни стилски немаркиран: „Какав ће очај обузети овај певачки и играчки, овај естрадерски Београд када се оконча овај рат!" (В3, 37). У истом духу и истим поводом, Ћосић од ос-

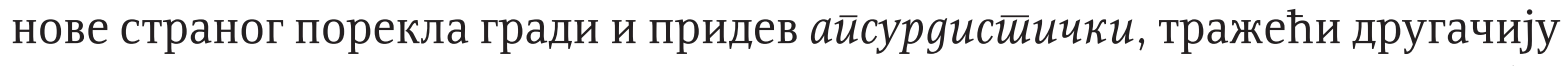
семантичку нијансу, вероватно 'склон апсурду', у односу на постојећи придев айсурgан (РМС: 'логички немогућ; бесмислен, неприличан, смешан'): „Ти карневалски призори по Београду и српским градовима, чине наш херојски рат гротескним и апсурдистичким" (B3, 42). ${ }^{6}$ Занимљив је

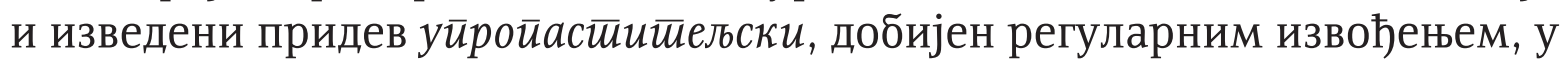
којем творбена основа настаје од постојеће али ретке именице уйройас-

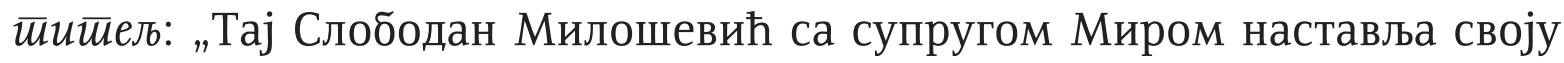
упропаститељску политику" (В3, 192).

При творби нових именица Ћосић посеже и за новим и старим суфиксима, суфиксима страног порекла који стварају и нове, високофреквентне творбене типове у публицистици, попут изведеница са онимима у основи и суфиксима -изащија и -изам: а) вијеитнамиащија: „Водила је најсуровији геноцидни рат у Вијетнаму; продужила своју вијетнамизацију Азије ратом против Ирака и Авганистана" (В3, 33); б) клинтионизам: „Двадесети век се окончава идеологијом клинтонизма; то је идеологија америчког тријумфалног и глобалистичког империјализма; то је идеологија људских права инструментализованих за циљеве господарења светом" (B3, 34). Други пример показује Ћосићеву намеру да читаоцу опширно прецизира значење неологизма. Из политичког и публицистичког дискурса преузета је и изведеница, или барем њен творбени тип,

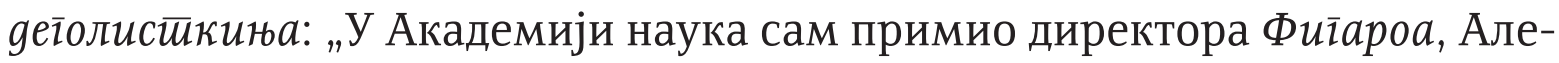
на Гиотреа, државног саветника Мари Гаро - деголисткињу, и два новинара" (B3, 37).

Од архаичне именице йолицај као мотивне настаје и Ћосићева изведеница йолии,јстиво, са јасним ироничним набојем који мањим делом обезбеђује пука застарелост основе, а више шаљив призвук који је овом германизму придаван временом махом код Срба у Војводини: „Европа је данас сатрап америчког хегемонизма, полицајства и контроле над малим и неразвијеним народима" (B3, 66).

Именицу gукљансииво, за коју можемо претпоставити да се појављивала и у језику тадашње публицистике, будући да је у Црној Гори постала

\footnotetext{
${ }^{6}$ Придева айсурguсиичики нема ни у Клајн/Шипка 2008.
} 
актуелна Дукљанска академија наука и умјетности, Ћосић у линеарном низу са градацијом употребљава иронично, као синоним за йлеменшйи-

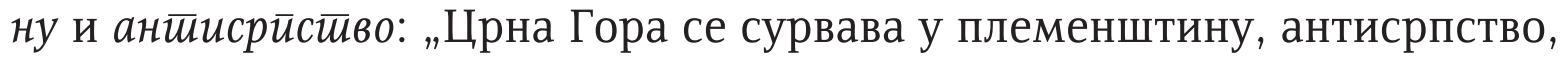
дукљанство" (В3, 240).

Један неологизам Ћосић је створио и помоћу суфиксоида -оug, такође творбеним средством које је постало карактеристично и за публицистички функционални стил, доносећи опет иронично сенчење, као и у пишчевој кованици устиашоug: „Тај подмукли усташоид пријављује и мене Хашком суду" (В3, 130).

Ћосић је индивидуалним неологизмима неретко попуњавао лексичке празнине у српском језику. Према постојећим лексемама нейа-

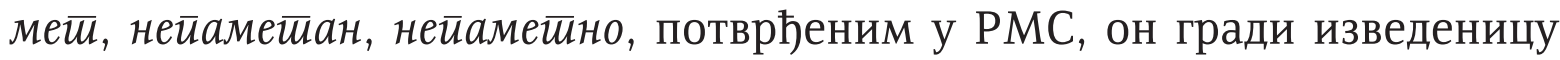

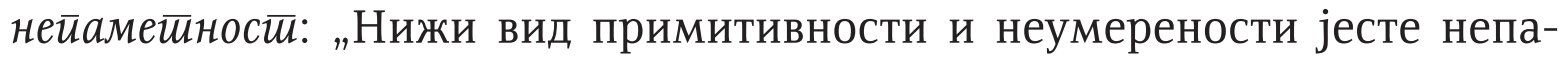
метност - константа карактера доброг дела Срба и Српкиња" (B3, 212).

Од предлошко-падежне конструкције йо сву ноћ Ћосић је извођењем сковао експресивни придев йосвуноћни: „Ови живи зидови људи, жена и деце на мостовима савским и дунавским, та посвуноћна одбрана мостова" (B3, 43).

Према предлошко-падежној конструкцији gо неба у РМС стоји само индивидуализам gонебан ('који стоји веома високо') са једним примером из Маретићевог превода, а Ћосић према конструкцији gо небе$c a$ гради и именицу gонебесник, са изразито позитивним конотацијама: „Патријарх Павле постаће донебесник морала и духовности” (B3, 206).

8. Многи Ћосићеви неологизми контекстуално су условљени. Међу наведеним примерима, неологизам свакочасовно директно семантички и синтаксички корелира са прилогом свакоgневно: „Телевизовано човечанство нас презире, јер се свакодневно, свакочасовно убеђује да смо извршили етничко чишћење и колективни злочин над Шиптарима" (B3,

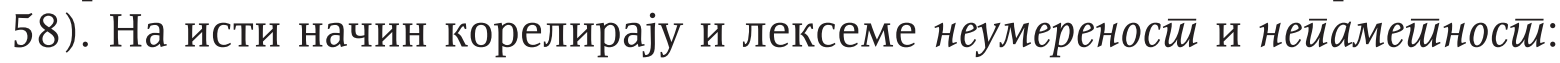
„Нижи вид примитивности и неумерености јесте непаметност - константа карактера доброг дела Срба и Српкиња" (B3, 212). Примери показују да постојеће лексеме постају модел за стварање нових, те коначан стилски ефекат Ћосићевих неологизама никако не можемо пресудити ван пуног реченичног контекста и корелацијама које постоје међу реченичним конституентима.

9. Посебно истраживање захтевала би и изненађујућа сликовитост Ћосићевих синагматских спојева, опет најчешће у функцији постизања

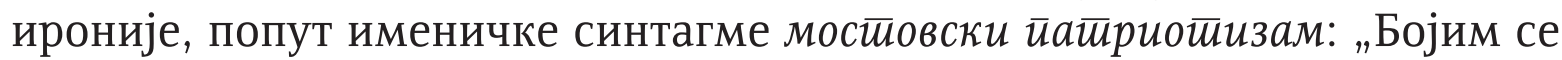
да мостовски патриотизам не смени деморализација" $(\mathrm{B} 3,60)$.

10. Уколико упоредимо примере и закључке о лексици у књизи Писици моїа века, која је објављена 2002. године (Милановић 2005: 239$244)$, видећемо да су многи стилски поступци остали Ћосићева констан- 
та. И у њој је писац активирао колоквијализме, додуше делом другачијег типа - што је условљено другачијим садржајем (слуіераюски, кумашин,

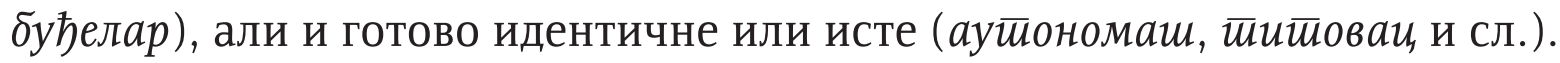
Ту су и ефектни неологизми (љуgолом, завичајсииво, изумник, свељуя-

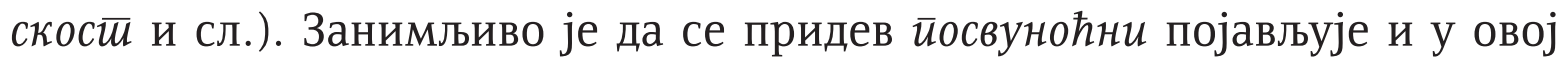
књизи.

11. Тешко је у радовима мањег обима, намењених тематским зборницима, представити анализиране феномене у свим детаљима. И многи мање присутни Ћосићеви лексичко-семантички поступци захтевали би у будућој монографији пажљиву анализу, попут графијско-ортографског посрбљавања речи странога порекла, као у примеру gенс макабр: „Њена посмртна песма, њен денс макабр, тј. игра смрти" (B3, 37).

Хетерогена стилски маркирана лексика у новијој дневничко-мемоарској прози, у којој коегзистирају вуларизми (сисе, їузови), пејорати-

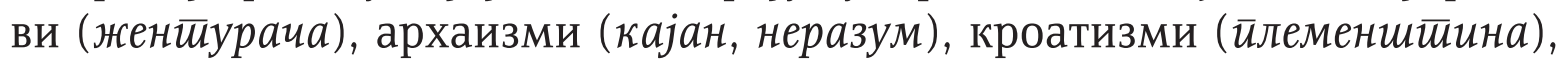

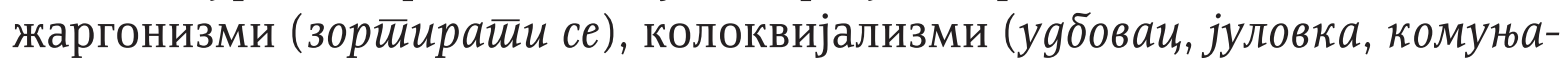

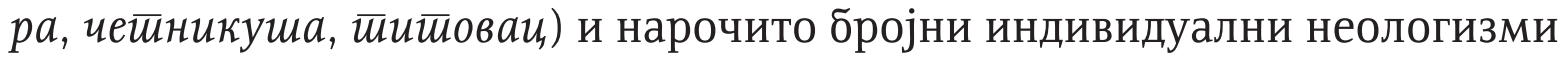
(млаяолешиан, gржавоборачки, свакочасовно, мостиобрански, млаяоужива-

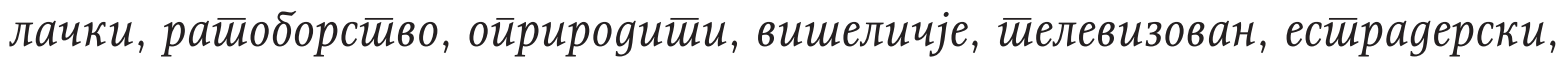

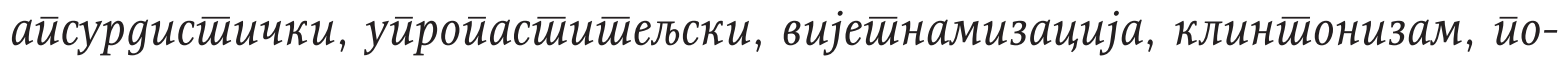

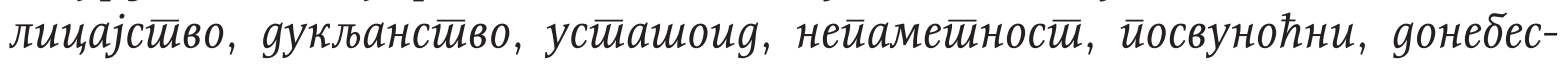
ник) сведочи да је и у њој Ћосић пажљиво одабирао и мозаички склапао лексичку структуру својих дела, остајући истовремено веран стилским поступцима и у својим романима и у претходним књигама сличног садржаја.

Ћосић је своју дневничко-мемоарску прозу појединим стилским поступцима у творби речи, њиховом избору и комбиновању сасвим приближио публицистици, нарочито журналистици у колумнама, а надамо се да наведени примери то довољно добро илуструју, и доказују. Тематика која подразумева и опис и наглашени лични коментар актуелних политичких и ратних збивања приближила је ова Ћосићева дела колумнама, што се морало одразити и на стил, нарочито на селектовану хетерогену лексику, у којој препознајемо велику ауторску слободу, али и постигнути склад.

И, на самоме крају, битна напомена. На основу постојећих анализа Ћосићеве лексике и богатства потврда, увиђа се и потреба израде речника пишчевих неологизама, како у дневничко-мемоарској прози, тако и у његовим романима. 


\section{ИЗВОРИ И СКРАЋЕНИЦЕ}

B3: Добрица Ћосић, Време змија, Београд: Службени гласник, 2008. Шт.

БР: Добрица Ћосић, Босански рай, Београд: Службени гласник, 2012. Шт.

\section{ЛИТЕРАТУРА}

Андрић, Драгослав. Двосмерни речник срӣскої жарі̄она и жарі̄ону сроgних речи и uзраза, Београд: Београдски издвачко-графички завод, 1976. Шт.

Gerzić, Borivoj. Rečnik srpskog žargona, Beograd: Caligraph, 2012. Št.

Драгићевић, Рајна. Срйска лексика у йрошлосиии и gанас, Нови Сад: Матица српска, 2018. Шт.

Клајн, Иван. Творба речи у савременом срйском језику. Први gео. Слаі̄аюе и йрефиксаи,ја, Београд - Нови Сад: Завод за уџбенике и наставна средства - Матица српска - Институт за српски језик САНУ, 2002. Шт.

Клајн, Иван. Творба речи у савременом срйском језику. Друіи део. Суфиксаиија и конверзија, Београд - Нови Сад: Завод за уџбенике и наставна средства - Матица српска - Институт за српски језик САНУ, 2003. Шт.

Клајн, Иван и Милан Шипка. Велики речник стираних речи и израза, треће допуњено и исправљено издање, Нови Сад: Прометеј, 2008. Шт.

Милановић, Александар. „Запажања о језику и стилу у делу Писци моїа века Добрице Ћосића", у: Писаи, и историја : зборник раgова о Добриии Ћосићу (ур. Верољуб Вукашиновић и Марко Недић), Трстеник - Београд: Народна библиотека „Јефимија" - Српска књижевна задруга, (2005): 239-253. Шт.

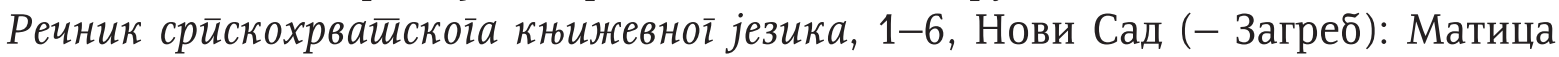
српска (- Матица хрватска), 1967-1976. Шт.

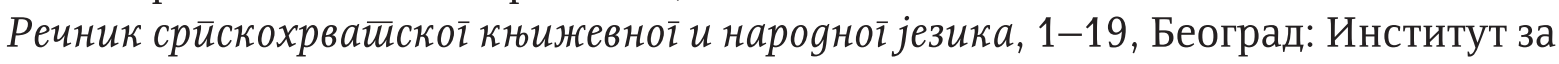
српски (српскохрватски) језик САНУ, 1959-2014. Шт.

Речник срйскоі̄a језика, Измењено и поправљено издање, Нови Сад: Матица српска, 2011. Шт.

Ћорић, Божо, Творба имении, у срииском језику (оgабране иеме), Београд: Друштво за српски језик и књижевност Србије, 2008. Шт.

Ћосић Вукић, Ана. „Напомена приређивача”, у: Добрица Ћосић, Босански рати, Београд: Службени гласник, (2012): 275-276. Шт. 
Aleksandar M. Milanović

ON THE LEXICAL FEATURES OF ĆOSIĆ'S DIARY-MEMOIR PROSE

\section{Summary}

The paper analyses the stylistically marked lexis in Ćosić's diary-memoir prose, the works The Bosnian War and A Time of Snakes: The Author's Records in 1999-2000: A Minor World War against Serbia - vulgarisms, pejoratives, archaisms, jargonisms, colloquialisms and particularly individual neologisms. The stylistically marked lexis, which also characterised Ćosić's previous works of similar nature, makes these works closer to publicistic literature, especially to columnist journalism. 